\title{
Nutrient losses in drainage and surface runoff from a cattle-grazed pasture in Southland
}

\author{
R.M. MONAGHAN ${ }^{1}$, R.J. PATON ${ }^{1}$, L.C. SMITH ${ }^{2}$ and C. BINET ${ }^{1}$ \\ ${ }^{1}$ AgResearch, Private Bag 50034, Mosgiel \\ ${ }^{2}$ AgResearch, 204 Woodlands-Morton Mains Road, RD1 Invercargill \\ ${ }^{1}$ monaghanr@agresearch.cri.nz
}

\section{Abstract}

In response to local concerns about the expanding Southland dairy herd, a 4-year study was initiated in 1995 with the primary objective of quantifying nitrate- $\mathrm{N}$ losses to waterways from intensively grazed cattle pastures. Treatments were annual $\mathrm{N}$ fertiliser inputs of $0,100,200$ or $400 \mathrm{~kg} \mathrm{~N} / \mathrm{ha}$. Stocking rate was set according to the pasture production on each of these four treatments, and over the 4 years of study ranged between the equivalent of 2.0 cows/ha for the $0 \mathrm{~N}$ treatment, to 3.0 cows/ha for the treatment receiving $400 \mathrm{~kg} \mathrm{~N} /$ ha/year.

Mean annual losses of nitrate- $\mathrm{N}$ in drainage were $30,34,46$ and $56 \mathrm{~kg} \mathrm{~N} / \mathrm{ha}$ for the $0,100,200$ and $400 \mathrm{~kg} \mathrm{~N} / \mathrm{ha} /$ year treatments, respectively. Corresponding mean nitrate- $\mathrm{N}$ concentrations in drainage waters were $8.3,9.2,12.5$ and $15.4 \mathrm{mg} /$ 1 , respectively. Very little direct leaching of fertiliser $\mathrm{N}$ was observed, even for drainage events in early spring, shortly after urea fertiliser application. The increased nitrate-N losses at higher rates of $\mathrm{N}$ fertiliser addition were instead owing to the indirect effect of increasing returns of urine and dung $\mathrm{N}$ to pasture. In Years 2 and 3, leaching losses of $\mathrm{Ca}, \mathrm{Mg}, \mathrm{K}, \mathrm{Na}$ and sulphate-S averaged $61,9,11,28$ and $17 \mathrm{~kg} / \mathrm{ha} /$ year, respectively, in the $0 \mathrm{~N}$ fertiliser treatment. Increasing fertiliser $\mathrm{N}$ inputs significantly increased calcium and, to a lesser extent, potassium leaching losses but had no effect on losses of other plant nutrients. Surface runoff losses of Total-P, nitrate-N and ammonium$\mathrm{N}$ were less than $0.5 \mathrm{~kg} / \mathrm{ha} / \mathrm{year}$. For this well-drained Fleming soil, surface runoff was a relatively minor contributor of $\mathrm{N}$ to surface water, even for plots receiving high rates of fertiliser $\mathrm{N}$ and at a stocking rate of 3.0 cows/ha.

Extrapolating these results to a 'typical' dairy pasture in Eastern Southland would suggest that the safe upper limit for annual fertiliser $\mathrm{N}$ additions to this site to achieve nitrate in drainage water below the drinking water standard is approximately $170 \mathrm{~kg} \mathrm{~N} / \mathrm{ha}$. Although losses of Ca in drainage were large, returns of this nutrient in maintenance applications of superphosphate-based products and lime should ensure $\mathrm{Ca}$ deficiencies are avoided in Southland dairy pastures.

Keywords: cation-anion balances, dairy, N fertiliser, nitrate leaching, surface runoff, Southland

\section{Introduction}

Increasing attention, both locally and internationally, is being focused on the sustainability of modern agricultural production systems, including New Zealand's dairy industry. Part of this attention has been directed at the perceived impacts that intensive farming systems have on water quality. Many rural communities in New Zealand rely on groundwater as the sole source of domestic drinking water, and current World Health Organisation (WHO) and New Zealand Ministry of Health (1995) guidelines recommend that nitrate- $\mathrm{N}$ concentrations in drinking water should be below $11.3 \mathrm{mg} / \mathrm{l}$. To ensure New Zealand retains its present 'clean green' image, thus adding value to our exported produce, it is essential that our pastoral industries are proven to have minimal detrimental effects on the wider environment. Although the importance of cow urine patches as a source of leached nitrate-N has been well documented (Clough et al. 1996; Fraser et al. 1994; Silva et al. 1999), there are relatively few studies on nutrient losses from grazed pasture under New Zealand conditions. In one study Ledgard et al. (1999) detailed N leaching losses from intensively grazed dairy farmlets in Waikato under varying rates of fertiliser $\mathrm{N}$ input, and in another study, Steele et al. (1984) reported cation and anion leaching losses from a cattle-grazed Northland pasture under conditions of high rainfall.

In Southland, which has seen a steady increase in dairy cow numbers over the past 10-12 years, concern has been expressed about the impact this expansion is having on ground and surface water quality in the region, particularly in relation to elevated levels of nitrate- $\mathrm{N}$ in groundwater, and phosphorus in surface waters. Concentrations of dissolved reactive phosphorus (DRP) greater than 15-30 $\mu \mathrm{g} / \mathrm{L}$, and dissolved inorganic nitrogen (DIN) greater than $40-100 \mu \mathrm{g} / \mathrm{L}$, are thought to encourage the nuisance growth of weeds and algae in surface waters (MfE 1992). In response to these 
concerns, a field study was initiated in eastern Southland in 1995 to (i) quantify subsurface drainage and surface runoff from cattle-grazed pastures as sources of $\mathrm{N}$ and $\mathrm{P}$ in waterways, (ii) identify a 'safe' upper limit for annual $\mathrm{N}$ fertiliser additions to Southland dairy pastures, and (iii) quantify losses of other important plant nutrients in subsurface drainage. This paper presents a summary of the results from this field study.

\section{Materials and methods}

\section{Location of experimental site}

The experimental site is located in eastern Southland, approximately $4 \mathrm{~km}$ west of the Edendale township. The site is flat to undulating, with a slope ranging from 0 to $4^{\circ}$. Average annual rainfall for this area is approximately $1000 \mathrm{~mm}$, with an average annual surplus rainfall (drainage) of approximately $350 \mathrm{~mm}$. The soil is a Fleming silt loam (mottled fragic Pallic soil), which has poor natural drainage owing to a slowly permeable B horizon at $50-80 \mathrm{~cm}$ depth.

\section{Experimental treatments}

Nutrient losses in drainage and surface runoff were examined under four rates of fertiliser $\mathrm{N}$ input: 0,100 , 200 or $400 \mathrm{~kg} \mathrm{~N} / \mathrm{ha} / \mathrm{yr}$, applied as urea. These treatments are subsequently referred to as $0 \mathrm{~N}, 100 \mathrm{~N}, 200 \mathrm{~N}$ and $400 \mathrm{~N}$, respectively. Each treatment was replicated three times in a randomized block design, with plot sizes of 0.09 ha. Fertiliser $\mathrm{N}$ was applied in individual split applications of $50 \mathrm{~kg} \mathrm{~N} / \mathrm{ha}$, with the broad aim of producing extra spring and autumn pasture growth. Thus, in the $100 \mathrm{~N}, 200 \mathrm{~N}$ and $400 \mathrm{~N}$ treatments, 50 units of fertiliser $\mathrm{N}$ was applied in early August and then again in early March, with the $200 \mathrm{~N}$ and $400 \mathrm{~N}$ receiving additional $\mathrm{N}$ applications in the following one or two grazing rounds, respectively. Because of the extra pasture grown in the $\mathrm{N}$-fertilised treatments, stocking rate varied between treatments to ensure that all pasture grown was eaten. During the first growing season of 1995/96, no fertiliser $\mathrm{N}$ was applied to any of the plots and this first year was thus run as a 'control' year. Nitrogen fertiliser treatments commenced in the spring of 1996, and the mean results presented here are for the subsequent 3 years of measurement.

A mixture of heifers, 2-5-year-old steers and dry cows were used to graze the plots at approximately 4weekly intervals between early August and late May. Nil winter grazing is a common management practice in this part of Southland, a strategy that has evolved mainly to protect pastures from pugging damage during the wet winter period. Plots were grazed to a constant pasture residual of approximately $1500-1600 \mathrm{~kg} \mathrm{DM} /$ ha.

\section{Drainage and surface runoff collection}

In spring 1995, a mole and tile drainage system was installed to capture drainage water from each of the 12 plots. Plots were hydrologically isolated by installing a separate mole and tile drainage system within each plot. Moles were pulled at $1.8 \mathrm{~m}$ spacings into a clay tile line that was overlain with gravel. Drainage water samples from the outflow of each plot were collected on a flow-proportional basis and stored for later analysis of cation and anion concentrations.

In the spring of 1997, surface runoff collectors were also installed on the downslope boundary of the $0 \mathrm{~N}$ and $400 \mathrm{~N}$ plots. These collectors consisted of PVC guttering linked to large tipping buckets for counting runoff volumes. A siphon collection system retained $0.1-0.2 \%$ of the runoff water passing through the tipping bucket apparatus. Surface runoff water samples were collected and stored at the end of each runoff event. Six smaller surface runoff plots $(0.05$ ha) were also established adjacent to the main plots, and instrumented to examine runoff losses from the undrained version of this soil, under both treatments. Stocking rates in these undrained plots were set as for the drained $0 \mathrm{~N}$ and $400 \mathrm{~N}$ treatments.

\section{Data analysis}

Annual nutrient losses were calculated based on the measured nutrient concentration multiplied by estimated drainage or surface runoff volume. Measured recoveries of drainage water varied across the site, ranging from approximately $20-40 \%$ recovery in the four lowestyielding plots (Block 1) to more than $80 \%$ recovery in the four highest yielding plots (Block 3 ). For this reason, drainage volumes were calculated from measured rainfall inputs to the site minus evapotranspiration, corrected for changes in soil moisture content. Treatments were allocated to plots to ensure there was one treatment replicate for each of the low-medium- and high-yielding plots. High-yielding plots were generally found to have slightly lower nitrate concentrations than low-yielding plots, presumably owing to these plots being at the toe of the slope and therefore less well-drained than the lower yielding plots in Block 1. One plot from the $400 \mathrm{~N}$ treatment was later found to have water encroachment onto the plot from surrounding areas and was therefore excluded from the data analysis. Nutrient leaching losses from each plot were analysed by analysis of variance of a randomised block design, using the statistical package Genstat 5 (Genstat 1997). Box's test for symmetry of the covariance matrix was performed; non-significance of this result was taken as evidence for justifying Years being treated as a subplot. Using this analysis, the linear component of $\mathrm{N}$ rate was significant $(\mathrm{P}<0.05)$. 


\section{Results}

\section{Nutrient losses in drainage}

Calculated drainage volumes ranged from $309 \mathrm{~mm}$ in 1998 to $437 \mathrm{~mm}$ in 1999. Annual nitrate-N losses in the $0 \mathrm{~N}$ treatment, which relied solely on clover fixation for supplying N, were low at $30 \mathrm{~kg} \mathrm{~N} /$ ha (Figure 1a). In the $100 \mathrm{~N}, 200 \mathrm{~N}$ and $400 \mathrm{~N}$ treatments, annual nitrate$\mathrm{N}$ losses in drainage waters were 34,46 and $56 \mathrm{~kg} / \mathrm{ha}$, respectively. Stocking rate equivalents, calculated from annual pasture intake in each of the treatments, ranged from $2.0 \mathrm{cows} / \mathrm{ha}$ in the $0 \mathrm{~N}$ treatment to $3.0 \mathrm{cows} / \mathrm{ha}$ in the $400 \mathrm{~N}$ treatment.

Figure 1 Nitrate leaching losses under varying $\mathrm{N}$ inputs and stocking rates, represented as (a) mean annual amounts leached (kg N/ha/year), and (b) mean nitrate-N concentrations in drainage water $(\mathrm{mg} / \mathrm{l}$, dotted lines represent upper and lower 95\% Confidence Limits).
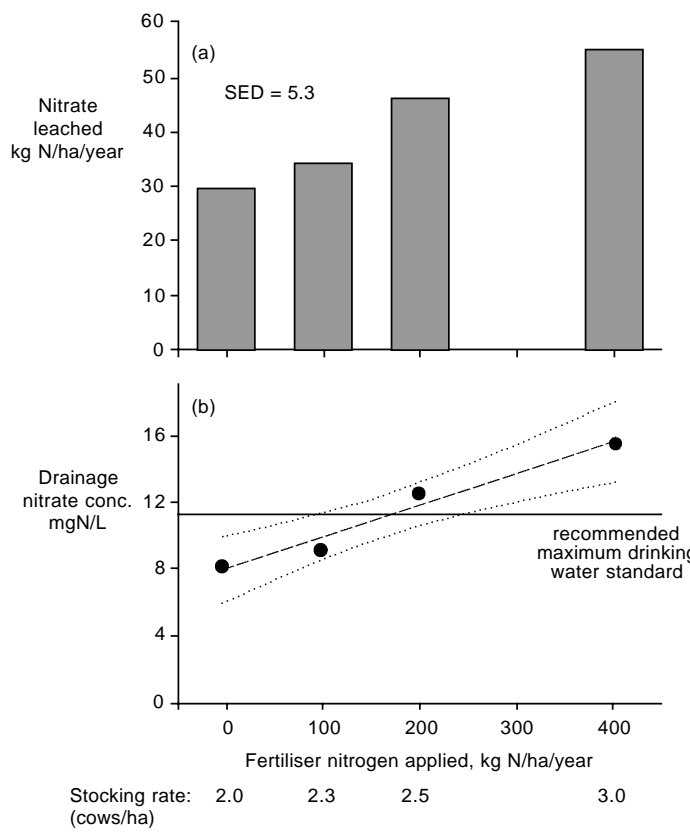

The mean nitrate- $\mathrm{N}$ concentrations in the drainage water ranged from 8.3 to $15.4 \mathrm{mg} / \mathrm{l}$ (Figure $1 \mathrm{~b}$ ). If the current WHO standard for nitrate in drinking water of $11.3 \mathrm{mg} / \mathrm{l}$ is used to define what is an 'acceptable' upper limit of $\mathrm{N}$ loss from these pastures, the losses in the $200 \mathrm{~N}$ and $400 \mathrm{~N}$ treatments exceeded this limit. Regression analysis of these data suggest that the upper limit for annual fertiliser additions to this site without exceeding the WHO guideline would be approximately $170 \mathrm{kgN} / \mathrm{ha}$.

The amounts of other important plant cations and anions lost in the drainage are shown in Table 1.
With the exception of dissolved reactive phosphorus (DRP) losses, which were measured during 1998 only, these data represent the mean annual losses of these nutrients during 1997 and 1998. The dominant cation leached was calcium. Calcium and potassium losses increased significantly $(\mathrm{P}<0.05)$ as $\mathrm{N}$ input and stocking rate increased. For the remaining nutrients, $\mathrm{N}$ input had no significant effect on cation or anion leaching losses.

Table 1 Mean annual cation and anion losses in drainage (kgt ha).

\begin{tabular}{lcccccc}
\hline Inputs/outputs & $\mathrm{Ca}$ & $\mathrm{Mg}$ & $\mathrm{K}$ & $\mathrm{Na}$ & sulphate-S & $\mathrm{DRP}^{1}$ \\
\hline Inputs $^{2}$ & 172 & 6 & 1 & 21 & 98 & $\mathrm{na}^{3}$ \\
Drainage loss: & & & & & & \\
ON & 61 & 9 & 11 & 28 & 17 & 0.25 \\
$100 \mathrm{~N}$ & 63 & 10 & 10 & 27 & 18 & 0.10 \\
$200 \mathrm{~N}$ & 74 & 9 & 19 & 29 & 18 & 0.17 \\
$400 \mathrm{~N}$ & 87 & 9 & 17 & 25 & 16 & 0.25 \\
$\mathrm{SED}$ & 9 & 1 & 3 & 4 & 2 & 0.08 \\
\hline 1 & Dissolved Reactive & Phosphorus & losses in drainage & water \\
& measured during 1998 only. \\
& via fertiliser and rainfall. Rainfall inputs estimated from Boswell \\
et al. (1992). & 50 kg P/ha applied as superphosphate in March 1998. \\
\hline
\end{tabular}

Concentrations of DRP in drainage water were found to be quite variable, both within individual drainage events and between events. Within individual drainage events, DRP concentrations appeared to be closely correlated to sample turbidity and/or sediment levels. Sediment levels were observed to be greatest at the beginning of each drainage event and then decreased within 2-3 hours of drainage commencing. Consequently, the mean DRP losses calculated in Table 1 are variable and show no consistent treatment effect. Dissolved Reactive $\mathrm{P}$ is thought to represent a more readily available form of $\mathrm{P}$ than that measured by Total P. Measurement of Total P concentrations, made on 120 selected samples where DRP concentrations were greater than $30 \mu \mathrm{g} \mathrm{P} / 1$, showed that DRP represented approximately $40 \%$ of the Total P load within the drainage waters. Extrapolating this result would suggest that Total $\mathrm{P}$ losses in drainage from this site were approximately $0.5 \mathrm{~kg} \mathrm{P} / \mathrm{ha} /$ year.

\section{$\mathbf{N}$ and $\mathbf{P}$ losses in surface runoff}

Fourteen runoff events were recorded during the first 18 months of measurement. Relative to the $300-400 \mathrm{~mm}$ of subsurface drainage measured and calculated annually for the drained plots, the amounts of surface runoff observed are comparatively low, particularly for the drained treatment where only $4 \mathrm{~mm}$ of surface runoff was measured (Table 2). For this drained soil, there 
was no difference between mean runoff amounts measured in the low $\mathrm{N}$ input/low stocking rate treatment versus the high $\mathrm{N}$ input/high stocking rate treatment. This is in contrast to that observed for the undrained soil, where the high stocking rate-high $\mathrm{N}$ input treatment increased surface runoff volume from 12 to $17 \mathrm{~mm}$, although this difference was not statistically significant $(\mathrm{P}>0.05)$.

Table 2 Annual $\mathrm{N}$ and $\mathrm{P}$ losses in surface runoff from drained and undrained plots.

\begin{tabular}{lccccc}
\hline & $\begin{array}{c}\text { Runoff } \\
(\mathrm{mm})\end{array}$ & $\begin{array}{c}\text { Total P } \\
(\mathrm{g} / \mathrm{ha})\end{array}$ & $\begin{array}{c}\mathrm{DRP} \\
(\mathrm{g} / \mathrm{ha})\end{array}$ & $\begin{array}{c}\mathrm{NO}_{3}{ }^{-} \mathrm{N} \\
(\mathrm{g} / \mathrm{ha})\end{array}$ & $\begin{array}{c}\mathrm{NH}_{4}{ }^{+-\mathrm{N}} \\
(\mathrm{g} / \mathrm{ha})\end{array}$ \\
\hline $\begin{array}{l}\text { Drained } \\
\text { ON }\end{array}$ & 4 & 65 & 14 & 23 & 18 \\
$\quad 400 \mathrm{~N}$ & 4 & 71 & 21 & 53 & 70 \\
Undrained & & & & & \\
$\quad$ ON & 12 & 96 & 28 & 136 & 91 \\
$\quad 400 \mathrm{~N}$ & 17 & 349 & 116 & 348 & 446 \\
& & & & & \\
& & & & & \\
$*$
\end{tabular}

The amounts of mineral $\mathrm{N}$ (ammonium and nitrate) and $\mathrm{P}$ lost in surface runoff were calculated using log-transformed data to obtain average nutrient loss values for each treatment. The nutrient losses tend to reflect the runoff trends: losses of mineral $\mathrm{N}$ and $\mathrm{P}$ from drained soil were low, even for the high $\mathrm{N}$ inputhigh stocking rate treatment (Table 2). For the undrained soil, however, mineral $\mathrm{N}$ and $\mathrm{P}$ losses increased, particularly for the high stocking rate treatment where Total $\mathrm{P}$ losses were 2-7 times greater than those recorded in the drained soil.

\section{Discussion}

The nitrate leaching losses observed in the 200 and $400 \mathrm{~N}$ treatments in this study are low relative to that reported in a long-term grazing study carried out in Waikato, New Zealand. In a 5-year grazing study reported by Ledgard et al. $(1999 ; 2000)$, mean annual nitrate leaching losses of 28, 61 and $127 \mathrm{~kg} \mathrm{~N} / \mathrm{ha} /$ year were recorded for dairy farmlets receiving 0, 200 and $400 \mathrm{~kg}$ fertiliser N/ha/year, respectively. Corresponding losses in our study were 30,46 and $56 \mathrm{~kg} \mathrm{~N} / \mathrm{ha} /$ year, for the same treatments, respectively. The leaching losses measured in the unfertilised treatments of the Waikato and Southland studies are similar to those calculated for irrigated Canterbury soils not receiving $\mathrm{N}$ fertiliser, where lysimeter measurements of $\mathrm{N}$ leaching suggested paddock scale losses of $33 \mathrm{~kg} \mathrm{~N} /$ ha/year (Silva et al. 1999).

The greater drainage volumes and higher $\mathrm{N}$-fixation inputs recorded in the study by Ledgard et al. (1999) may have contributed to the greater nitrate leaching losses observed in the $\mathrm{N}$-fertilised treatments at the Waikato site. The absence of winter grazing at the Southland site probably also reduced nitrate leaching losses. Seasonal soil sampling of the Southland site revealed that, relative to fertiliser $\mathrm{N}$ inputs, little mineral $\mathrm{N}$ accumulated in the soil profile of the $200 \mathrm{~N}$ and $400 \mathrm{~N}$ treatments. This suggests that immobilisation of fertiliser $\mathrm{N}$ by soil organic matter or gaseous loss of $\mathrm{N}$ occurred, which could explain the lower nitrate leaching losses in the $\mathrm{N}$-fertilised treatments. Current research at the Edendale site is examining whether this process is a significant sink for fertiliser $\mathrm{N}$, and if so, how long this sink remains active. If it is shown that immobilisation is only a temporary sink for added $\mathrm{N}$ fertiliser, the upper limit for annual fertiliser additions calculated for this site (approximately $170 \mathrm{kgN} / \mathrm{ha}$ ) is probably too high and will need to be revised accordingly. Preliminary measurements of rates of $\mathrm{N}$ loss into the atmosphere by denitrification indicate that losses via this process are less than $10 \%$ of fertiliser $\mathrm{N}$ input, and thus cannot explain the difference in nitrate leaching losses between the Waikato and Southland studies.

Losses of other important plant nutrients in drainage were significant, although the amounts leached were often less than those returned in fertiliser and rainfall. Rainfall nutrient inputs to the Edendale site were obtained from Boswell et al. (1992), who measured rainfall nutrient inputs along five transects in Southland. Nutrient surpluses (fertiliser + rainfall inputs - drainage losses) were observed for $\mathrm{Ca}$ and $\mathrm{S}$, where considerable quantities of these nutrients were added to the soil in the superphosphate-based fertilisers used for maintenance $\mathrm{P}$ and $\mathrm{S}$ applications. This large Ca-fertiliser input, combined with regular $\mathrm{Ca}$ additions via lime, should ensure that $\mathrm{Ca}$ deficiency is avoided on most Southland dairy farms. Deficiencies may occur, however, in situations where high analysis fertilisers (i.e., low $\mathrm{Ca}$ ) replace superphosphate-based products. Sodium and $\mathrm{Mg}$ returns in rainfall and fertiliser almost balanced leaching losses of these two nutrients. In the case of $\mathrm{Mg}$, this finding contrasts with that found in the Waikato study, where measured leaching losses of $30 \mathrm{~kg} \mathrm{Mg} / \mathrm{ha} /$ year have contributed to a significant $\mathrm{Mg}$ deficit and consequent depletion of soil Mg reserves (Ledgard \& O'Connor 1998). An approximate Mg balance estimated for a 'typical' Southland dairy farm, based on the leaching losses measured in this study, shows that $\mathrm{Mg}$ inputs are roughly equal to $\mathrm{Mg}$ losses, and the system is thus in balance (Figure 2). In the case of $\mathrm{Na}$, estimated annual losses in drainage, animal transfer and product removal exceeded inputs by approximately $14 \mathrm{~kg} /$ ha (Figure 3 ). Although in this 
study pasture $\mathrm{Na}$ concentrations were above minimum levels thought to limit cow performance, pasture testing should be carried out to ensure $\mathrm{Na}$ status is adequate in inland areas which receive lower $\mathrm{Na}$ inputs via rainfall.

Figure 2 Magnesium inputs and losses from a typical Southland dairy farm (kg Mg/ha/year).

\section{Magnesium}

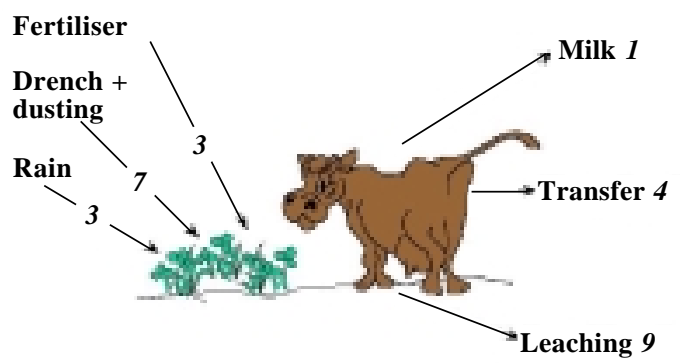

Total in $=13$

Total out $=14$

Figure 3 Sodium inputs and losses from a typical Southland dairy farm (kg Na/ha/year).

Sodium

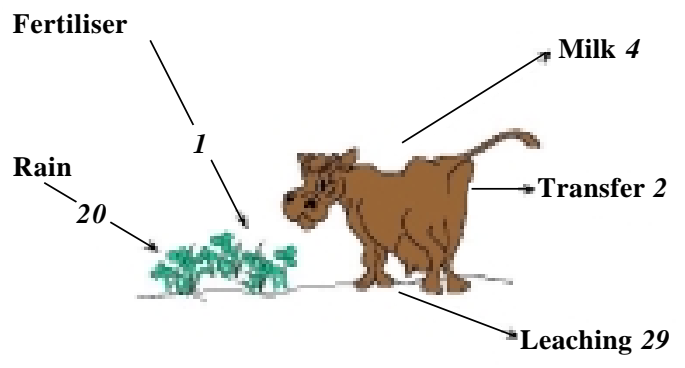

Total in $=21$

Total out $=35$

Surface runoff from the well-drained Fleming soil studied here was a relatively minor contributor of $\mathrm{N}$ and $\mathrm{P}$ to surface water, even for plots receiving $400 \mathrm{~kg}$ fertiliser N/ha/year and stocked at over 3.0 cows/ha. Where this soil was left undrained, however, $\mathrm{N}$ and $\mathrm{P}$ losses in surface runoff increased considerably, particularly in the $400 \mathrm{~N}$ treatment. Although the volumes of surface runoff from the undrained soil were still small relative to the $370 \mathrm{~mm}$ of surplus rainfall calculated for this site, the relatively high concentrations of $\mathrm{P}$ in this surface runoff resulted in a large increase in P loss. While the Fleming soil is well-structured, and therefore relatively resistant to pugging, greater $\mathrm{P}$ and $\mathrm{N}$ losses might be expected on more weakly structured soil types.

\section{Conclusion}

Monitoring of nutrient losses in drainage waters indicated that nitrate leaching losses to groundwater are unlikely to exceed the drinking water quality standard at low to modest rates of $\mathrm{N}$ fertiliser use on cattle-grazed pastures in Southland. However, it is recommended that total fertiliser $\mathrm{N}$ applications to Southland pastures do not exceed $170 \mathrm{~kg} / \mathrm{ha} /$ year. Losses of $\mathrm{Ca}, \mathrm{Mg}, \mathrm{K}, \mathrm{Na}$, and sulphate-S in drainage were significant, although the amounts leached were often less than those returned in fertiliser and rainfall. Increasing fertiliser $\mathrm{N}$ inputs significantly increased calcium and potassium leaching losses but had no effect on losses of other plant nutrients. For this welldrained Fleming soil, surface runoff was a relatively minor contributor of $\mathrm{N}$ to surface water, even for plots receiving high rates of fertiliser $\mathrm{N}$ and at a stocking rate of 3.0 cows/ha.

\section{ACKNOWLEDGEMENTS}

The authors gratefully acknowledge the support of the Foundation for Research, Science and Technology in their funding of this project. FertResearch funded cation-anion analyses of drainage waters. We also thank the following local companies who financially assisted in the set-up and running of this project: SouthFert, Hoffman Drainage Contractors Ltd and SouthTile Ltd.

\section{REFERENCES}

Boswell, C.C.; Risk, W.H.; Gray, G.M.; Swanney, B.; Parmenter, G.A.; Smith, L.C. 1992. Sulphur in rainfall in Southland, New Zealand. Invermay Technical Report No. 30. Invermay Agricultural Centre, Mosgiel. 31p.

Clough, T.J.; Sherlock, R.R.; Cameron, K.C.; Ledgard, S.F. 1996. Fate of urine nitrogen on mineral and peat soils in New Zealand. Plant and Soil 178: 141-152.

Fraser, P.M.; Cameron, K.C.; Sherlock, R.R. 1994. Lysimeter study of the fate of nitrogen in animal urine returns to irrigated pasture. European Journal of Soil Science 45: 439-447.

Genstat 1997. Statistical package; Genstat 5, Release 4.1. Rothamsted Experimental Station, United Kingdom, Lawes Agricultural Trust.

Ledgard, S.F.; O'Connor, M.B. 1998. Magnesium status slowly declining. Dairy Exporter, August: 66-67. 
Ledgard, S.F; de Klein, C.A.M.; Crush, J.R.; Thorrold, B.S. 2000. Dairy farming, nitrogen losses and nitratesensitive areas. Proceedings of the New Zealand Society of Animal Production 60: 256-260.

Ledgard, S.F.; Penno, J.W.; Sprosen, M.S. 1999. Nitrogen inputs and losses from clover/grass pastures grazed by dairy cows, as affected by nitrogen fertilizer application. Journal of Agricultural Science, Cambridge 132: 215-225.

MfE 1992. Water Quality Guidelines No. 1. Guidelines for the control of undesirable biological growths in water. $57 \mathrm{pp}$.
New Zealand Ministry of Health 1995. Drinking water standards for New Zealand. Ministry of Health. Wellington, 87pp.

Silva, R.G.; Cameron, K.C.; Di, H.J.; Hendry, T. 1999. A lysimeter study of the impact of cow urine, dairy shed effluent, and nitrogen fertiliser on nitrate leaching. Australian Journal of Soil Research 37: 357-369.

Steele, K.W.; Judd, M.J.; Shannon, P.W. 1984. Leaching of nitrate and other nutrients from a grazed pasture. New Zealand Journal of Agricultural Research 27: 5-11. 